The Chittagong Univ. J. Sci. 41(1) : 39-67, 2019

DOI: https://doi.org/10.3329/cujs.v41i1.51914

\title{
Determinants of Nutritional Status among School Girls in Chittagong Metropolitan Area
}

\author{
Md Abdul Karim* and Jesmin Akter \\ Department of Statistics, University of Chittagong, Chittagong - 4331, Bangladesh \\ *Corresponding author: makstatcu@yahoo.com
}

\begin{abstract}
This study aims to investigate the determinants of nutritional status (BMI) of school girls, selected randomly from the schools of Chittagong metropolitan area because good nutritional status is a pre-requisite for good health, fertility and national productivity. The results of this study show that more than one-third (38.6\%) school girls belong to underweight, $47.9 \%$ normal and $13.5 \%$ overweight. The overall mean BMI of the selected girls is found $20.03 \pm 4.06 \mathrm{~kg} / \mathrm{m}^{2}$ with considerable variations by their background characteristics. The co-efficient of variation (20.27\%) indicates that there exists extreme heterogeneity in BMI of the respondents. Co-efficient of skewness $\left(\beta_{1}=0.85\right)$ and excess of kurtosis $\left(\gamma_{2}=1.05\right)$ reflect that the distribution of BMI is positively skewed and leptokurtic. The mean BMI is found relatively high among the respondents living in the metropolitan area $\left(21.18 \mathrm{~kg} / \mathrm{m}^{2}\right)$. The highest mean BMI is found among the girls belong to high family income group $\left(21.62 \mathrm{~kg} / \mathrm{m}^{2}\right)$ and low $\left(18.69 \mathrm{~kg} / \mathrm{m}^{2}\right)$ in lower family income group. Bivariate analysis indicates that religion, place of origin, place of residence, respondents' education, arm circumference, fathers and mothers education and occupation, family income, family size, sibling size, skipping and cycling, duration of sporting activity and sleeping, and food intake are found to have significant
\end{abstract}


association with nutritional status of the girls. The study also shows that BMI is significantly positively correlated with family income and negatively with duration of sporting activities. Multinomial logistic regression analysis illustrates that place of residence, arm circumference, mothers' occupation, duration of sleeping and food intake is found significant predictors of BMI.

Keywords: School girls, food intake, BMI, overweight, chi-square test, multicollinearity, multinomial logistic regression analysis.

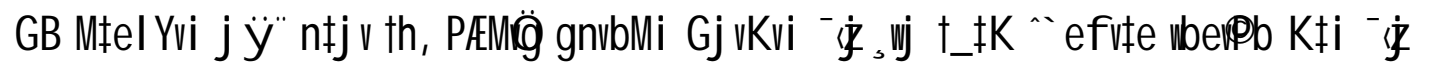

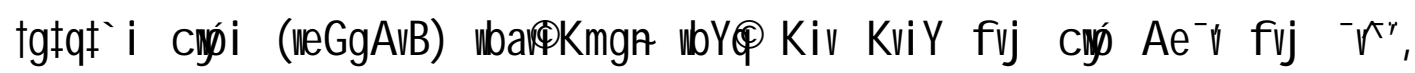

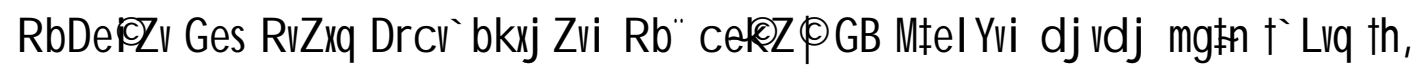

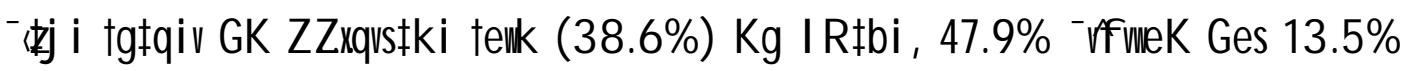

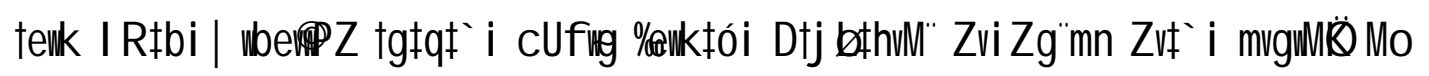

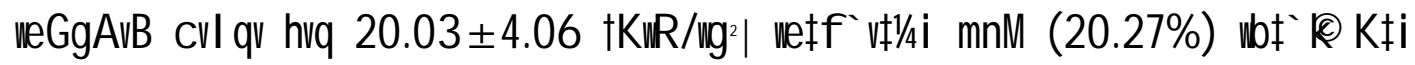
th, DËi ' Z优 i

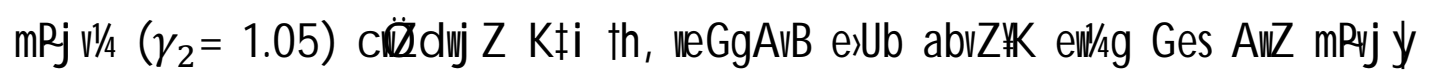

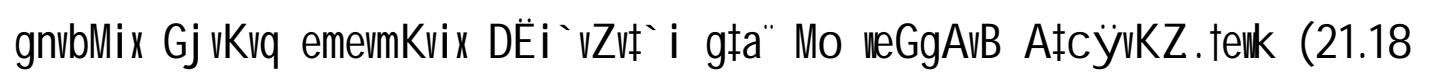

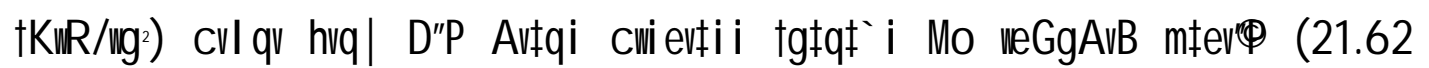

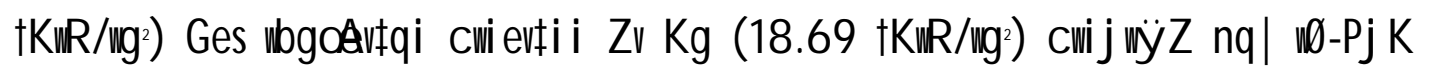

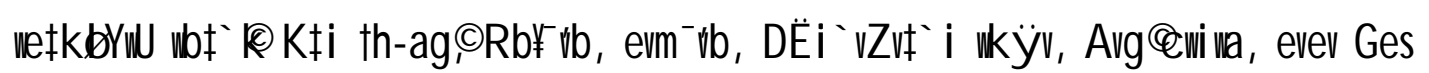

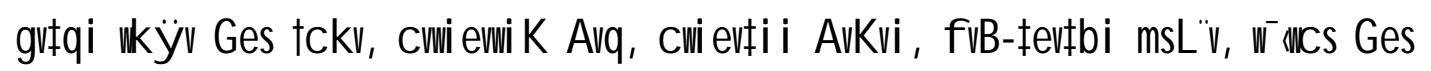

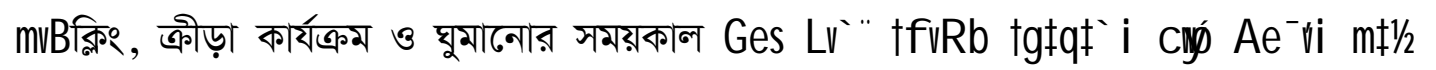




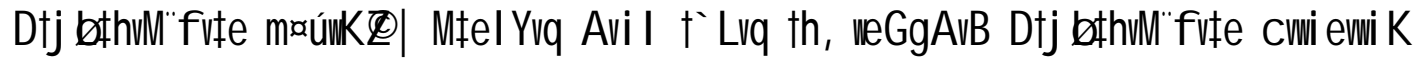

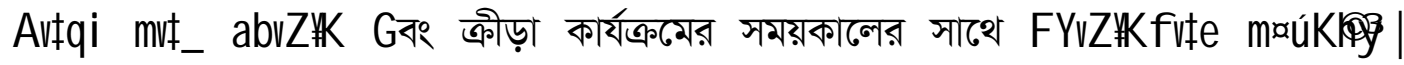

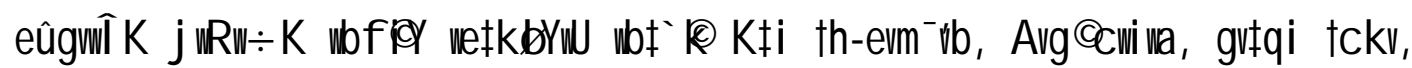 Nytbi ngoKy Ges Lv" "M̈̈b}

\section{Introduction}

The condition of health of a person, which is influenced by the intake and utilization of nutrients, is called nutritional status. Nutrition is an important determinant of physical growth, mental development and human reproductive characteristics. Female adequate nutrition is a pre-requisite for attaining good health, fertility and national productivity. Nutritional status is also an important determinant of vital events [1,2]. A good nutritional status represents a healthy nation providing better socio-economic status. On the other hand, poorly nourished females produce insufficient breast milk, inadequate colostrums and their milk is less nutritious than their well-nourished counterparts [3]. In developing countries, malnutrition is a medical as well as a social disorder [4]. Bangladesh along with India and Nepal belong to the 20 countries with the highest burden of malnutrition, which constitute $80 \%$ of the world's undernourished children [5]. Malnutrition is estimated to be an 'underlying cause' of about $60 \%$ of childhood deaths in Bangladesh [6]. Prevalence of stunting and underweight both remain unexpectedly high in Bangladesh. Chronic under-nutrition in female children is linked to slower cognitive development, poor school attendance and school withdrawal rate, and serious health impairments later in life that reduce the human productivity of life of individuals. Overweight and obesity have also been linked to increased risk of 
42 Md Abdul Karim and Jesmin Akter

cardiovascular disease, diabetes, irregular and painful menstruation, infant and maternal mortality as well as other chronic diseases [7]. Increased intra-uterine, perinatal and neonatal mortality, morbidity, a higher risk babies with low birth weight, stillbirths, and miscarriage are some of the consequences of malnutrition in women [8]. School-age malnutrition has negative influence on school performance. Malnutrition can impair the function of the human reproductive process [9]. The prevalence of obesity among school girls is increasing rapidly and obesity is becoming a major problem in urban areas of developing countries. The increasing prevalence of overweight and obesity is a critical health problem for female reproductive life. Moreover, obesity has been associated both short and long term health effect for female students.

\section{Objectives of the Study}

The main goal of this research study is to identify the important predictors of nutritional status among school girls using biological and social constructs. However, based on the purpose and its importance, the specific objectives of this research work are as follows:

i) To compute the overall mean BMI among selected school girls in Chittagong metropolitan area along with differentials by background characteristics;

ii) To investigate the socio-economic and demographic covariates and their implications on nutritional status (BMI) and;

iii) Finally, to recommend some suitable policies for better nutritional status of the students for better reproductive health $(\mathrm{RH})$ in future because $\mathrm{RH}$ is a 
human right stated in international law.

\section{Materials and Methods}

\subsection{Target Area and Population}

Chittagong metropolitan area was chosen as the target area for this study. The rationale behind to select Chittagong metropolitan area as the study area because this area is a cosmopolitan in nature, the standard of living of this area is relatively high and urban facilities are adequate. Furthermore, the girls living in this area are supposed to be relatively well-nourished and belong to be overweight stratum. The target population of this study was the school going girls from class 5 to 10 between age 9 and 15 years.

\subsection{Data Collection Procedure and Sample Size Determination}

This study was based on primary data which is an original, unique and first of its kind. The data was collected by personal interview method. First of all, a draft wellstructured interview schedule has been designed on the light of objectives of the study. Thereafter, pre-testing was carried out accordingly on the basis of 50 primarily selected school girls and the schedule was finalized for the field survey. For conducting this research work efficiently, 922 school girls out of 31350 have been selected by employing cluster sampling scheme using appropriate formula for the determination of sample size because the respondents within cluster are heterogeneous in the context of height, weight and arm circumference.

\subsection{Selection of Respondents and Data Analysis}

In this study, the list of schools in Chittagong metropolitan area was used as a 
44 Md Abdul Karim and Jesmin Akter

sampling frame. Cluster sampling design was considered to select the respondents for conducting this study. At first, the code numbers of all schools were written independently on separate sheet representing the clusters. In the second stage, 2 schools were randomly selected out of 51 schools (clusters) in Chittagong metropolitan area to make up the total sample size. The total number of female students aged 9-15 years in both the selected schools was 945 (484+461). Finally, information was collected from 922 ultimate sampling units because 23 respondents were reluctant to enter into the interview. The field survey of this study was conducted from April, 2018 to June, 2018 among selected school going girls in Chittagong metropolitan area. While conducting the field survey, the data was organized by field editing, coding, recoding and tabulation. Thereafter, the data was analyzed by using SPSS (version 24.0) and interpretations are done accordingly based on the results.

\section{Methodology}

First of all, descriptive statistics of BMI are computed to compare the levels, variability and shape characteristics by some selected background characteristics of the respondents. To observe the linear relationship and mean rate of change of BMI by the change of some selected quantitative explanatory variables, simple correlation and regression analyses are employed. To investigate the association between nutritional status and explanatory variables, contingency tables have been constructed along with chi-square test statistic and level of significance. To assess the multicollinearity problem among independent variables, Variance Inflation Factor (VIF) has been computed. To identify the independent effect of the factors on BMI, multinomial logistic regression 
has been employed considering the variables found significant in bivariate analysis because the dependent variable is tri-chotomous type. In addition to identify the influencing factors of nutritional status of selected school girls in Chittagong, a conceptual framework has been designed and presented below for understanding the factors at a glance.

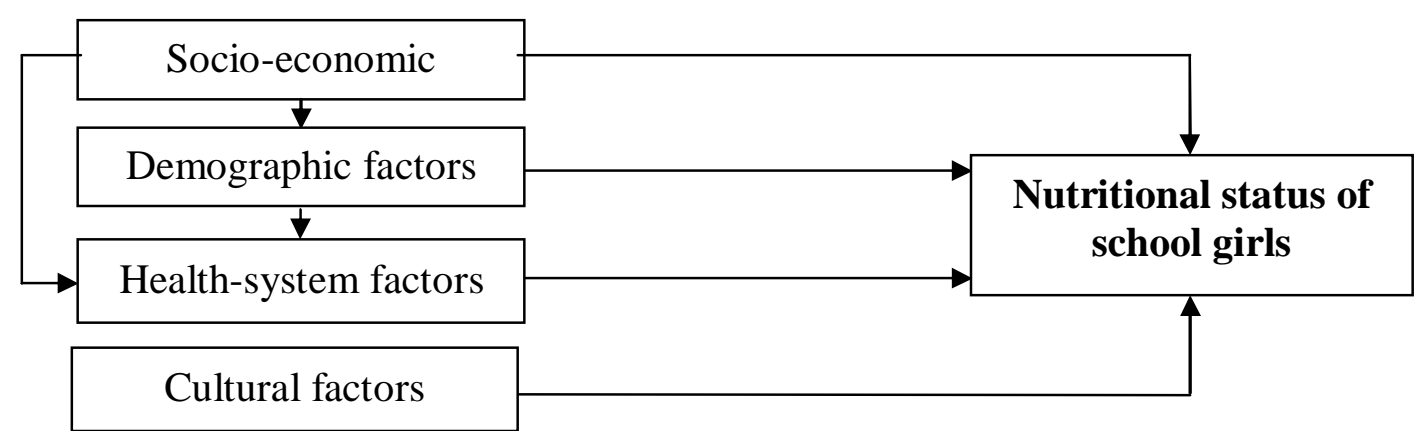

Fig. 1: Conceptual framework of nutritional status of school girls.

One of the most widely used inexpensive, non-invasive and universally applicable measures of nutritional status is body mass index (BMI). The BMI was invented by Adolphe Quetelet between 1830 and 1850. BMI is calculated by dividing a person's weight in kilograms by the square of their height in meters. The universally accepted formula of BMI is

$$
\mathbf{B M I}=\frac{\text { Weight }(\mathrm{kg})}{\text { Height }\left(\mathrm{m}^{2}\right)}
$$

In this study, BMI was divided into three groups and assigned the corresponding codes, such as, $<18.5 \mathrm{~kg} / \mathrm{m}^{2}=1$ (underweight); $18.50-24.99 \mathrm{~kg} / \mathrm{m}^{2}=2$ (normal weight) and $\geq 25.0 \mathrm{~kg} / \mathrm{m}^{2}=3$ (overweight).

\section{Results and Discussion}

Nutrition (BMI) is one of the most essential factors influencing the physical and 
reproductive characteristics of females. The descriptive statistics of BMI of this study are given in the Table 1 and the results illustrate that the mean weight of the respondents is $46.20 \pm 10.85 \mathrm{~kg}$, which indicates that the weight of the girls are extremely heterogeneous. The mean height of the respondents is $151.48 \pm 6.57 \mathrm{~cm}$, which is also heterogeneous. The mean arm circumference among the respondents is $14.46 \pm 1.15 \mathrm{~cm}$. The overall mean BMI of the selected respondents is $20.03 \pm 4.06$ $\mathrm{kg} / \mathrm{m}^{2}$, which reflects that the computed mean BMI is relatively lower. The coefficient of variation (C.V), co-efficient of skewness $\left(\beta_{1}\right)$ and excess of kurtosis $\left(\gamma_{2}\right)$ of the BMI are 20.27\%, 0.85 and 1.05 respectively. The results at a glance reflect that the BMI is widely heterogeneous among the respondents and the shape characteristics of BMI are positively skewed and leptokurtic.

Table 1. Summary measures of nutritional indicators of the respondents.

\begin{tabular}{ccccc}
\hline Anthropometric measures & Mean \pm S.D & C.V (\%) & $\boldsymbol{\beta}_{\mathbf{1}}$ & $\boldsymbol{\gamma}_{\mathbf{2}}$ \\
\hline Weight $(\mathbf{k g})$ & $46.20 \pm 10.85$ & 23.48 & 0.83 & 1.53 \\
Height $(\mathbf{c m})$ & $151.48 \pm 6.57$ & 4.34 & -0.38 & 1.01 \\
Arm Circumference (cm) & $14.46 \pm 1.15$ & 7.95 & 0.33 & 0.95 \\
BMI $\left(\mathbf{k g} / \mathbf{m}^{\mathbf{2}}\right)$ & $20.03 \pm 4.06$ & $\mathbf{2 0 . 2 7}$ & $\mathbf{0 . 8 5}$ & $\mathbf{1 . 0 5}$
\end{tabular}

In addition to the overall summary measures of BMI, it is in need to investigate the important factors influencing the BMI. Generally, different types of socioeconomic and demographic variables influence the nutritional status of females. In Bangladesh, researchers have investigated the relationship between BMI and mortality [10], and socio-economic and demographic factors [11,12]. Keeping its importance, the differentials of BMI by some selected background characteristics were computed along with chi-square test statistic and levels of significance and 
the findings are given in the Table 2.

Table 2. Percentage distribution of school girls by some selected background characteristics along with corresponding mean BMI.

\begin{tabular}{|c|c|c|c|c|c|}
\hline \multirow{2}{*}{$\begin{array}{l}\text { Background } \\
\text { characteristics }\end{array}$} & \multicolumn{3}{|c|}{ BMI $\left(\mathrm{kg} / \mathrm{m}^{2}\right)$} & \multirow{2}{*}{$\begin{array}{c}\text { Mean } \\
\text { BMI } \\
\left(\mathrm{kg} / \mathrm{m}^{2}\right)\end{array}$} & \multirow{2}{*}{$\begin{array}{c}\text { No. of } \\
\text { respondents }\end{array}$} \\
\hline & $<18.5$ & 18.50 to 24.99 & $\geq 25.0$ & & \\
\hline \multicolumn{6}{|c|}{$\begin{array}{c}\text { Respondents' current age } \\
\text { (years) }\end{array}$} \\
\hline $9-11$ & 8.7 & 8.7 & 2.3 & 19.20 & 181 \\
\hline $12-13$ & 19.4 & 27.2 & 8.6 & 20.45 & 509 \\
\hline $14-15$ & 10.5 & 12.0 & 2.6 & 19.76 & 232 \\
\hline \multicolumn{6}{|c|}{$\chi^{2}=8.12$} \\
\hline \multicolumn{6}{|l|}{ Religion } \\
\hline Muslim & 32.5 & 36.7 & 9.7 & 19.80 & 727 \\
\hline Others & 6.1 & 11.3 & 3.8 & 20.88 & 195 \\
\hline \multicolumn{6}{|c|}{$\chi^{2}=11.49^{* *}$} \\
\hline \multicolumn{6}{|l|}{ Place of origin } \\
\hline Rural & 27.3 & 34.7 & 7.8 & 19.77 & 644 \\
\hline Semi-urban & 2.9 & 4.0 & 2.2 & 21.36 & 84 \\
\hline Urban & 8.4 & 9.2 & 3.5 & 20.32 & 194 \\
\hline \multicolumn{6}{|c|}{$\chi^{2}=12.89^{*}$} \\
\hline \multicolumn{6}{|c|}{ Current place of residence } \\
\hline Semi-urban & 26.0 & 22.3 & 3.5 & 18.96 & 478 \\
\hline Urban & 12.6 & 25.6 & 10.0 & 21.18 & 444 \\
\hline \multicolumn{6}{|c|}{$\chi^{2}=73.11^{* *}$} \\
\hline & & & & \multicolumn{2}{|c|}{ Table 2 continued } \\
\hline \multicolumn{6}{|c|}{$\begin{array}{c}\text { Respondents' educational } \\
\text { level }\end{array}$} \\
\hline $\begin{array}{c}\text { (class) } \\
5\end{array}$ & $\begin{array}{c}3.5 \\
27.8\end{array}$ & $\begin{array}{c}3.6 \\
37.1\end{array}$ & $\begin{array}{r}0.5 \\
11.5\end{array}$ & 18.48 & $\begin{array}{c}70 \\
704\end{array}$ \\
\hline 6 to 8 & $\begin{array}{l}2.0 \\
7.4\end{array}$ & 7.3 & 1.4 & 20.28 & 148 \\
\hline \multirow[t]{2}{*}{9 to 10} & & & & 19.58 & \\
\hline & & $\chi^{2}=10.01^{*}$ & & & \\
\hline
\end{tabular}




\begin{tabular}{|c|c|c|c|c|c|}
\hline \multirow{2}{*}{$\begin{array}{l}\text { Background } \\
\text { characteristics }\end{array}$} & \multicolumn{3}{|c|}{ BMI $\left(\mathrm{kg} / \mathrm{m}^{2}\right)$} & \multirow{2}{*}{$\begin{array}{c}\text { Mean } \\
\text { BMI } \\
\left(\mathrm{kg} / \mathrm{m}^{2}\right)\end{array}$} & \multirow{2}{*}{$\begin{array}{l}\text { No. of } \\
\text { respondents }\end{array}$} \\
\hline & $<18.5$ & 18.50 to 24.99 & $\geq 25.0$ & & \\
\hline \multicolumn{6}{|l|}{ Arm Circumference (cm) } \\
\hline$\leq 13.9$ & 21.8 & 6.5 & 0.5 & 16.80 & 266 \\
\hline $14.0-15.5$ & 16.3 & 36.9 & 4.7 & 20.34 & 533 \\
\hline Above 15.5 & 0.5 & 4.6 & 8.2 & 25.68 & 123 \\
\hline \multicolumn{6}{|c|}{$x^{2}=467.4^{* *}$} \\
\hline \multicolumn{6}{|l|}{ Fathers education } \\
\hline Below secondary & 5.1 & 3.4 & 0.5 & 18.26 & 83 \\
\hline Secondary & 9.1 & 7.5 & 0.5 & 18.52 & 158 \\
\hline Above secondary & 24.4 & 37.1 & 12.4 & 20.59 & 681 \\
\hline \multicolumn{6}{|c|}{$\chi^{2}=45.71^{* *}$} \\
\hline \multicolumn{6}{|l|}{ Mothers education } \\
\hline Below secondary & 5.2 & 4.3 & 0.7 & 18.51 & 94 \\
\hline Secondary & 11.8 & 10.8 & 1.5 & 19.05 & 223 \\
\hline Above secondary & 21.6 & 32.8 & 11.3 & 20.63 & 605 \\
\hline \multicolumn{6}{|c|}{$\chi^{2}=34.81^{* *}$} \\
\hline \multicolumn{6}{|l|}{ Fathers Occupation } \\
\hline Business & 14.6 & 16.8 & 5.6 & 20.06 & 342 \\
\hline Service & 14.8 & 21.9 & 7.0 & 20.55 & 403 \\
\hline Others & 9.2 & 9.2 & 0.8 & 18.80 & 177 \\
\hline \multicolumn{6}{|c|}{$\chi^{2}=22.29^{* *}$} \\
\hline \multicolumn{6}{|l|}{ Mothers Occupation } \\
\hline House wife & 32.4 & 36.4 & 10.3 & 19.91 & 730 \\
\hline Service & 6.2 & 11.5 & 3.1 & 20.49 & 192 \\
\hline \multicolumn{6}{|c|}{$\chi^{2}=8.17^{*}$} \\
\hline
\end{tabular}

Table 2 continued

\begin{tabular}{cccccc}
$\begin{array}{c}\text { Monthly family income } \\
\text { (Tk.) }\end{array}$ & 15.0 & 11.9 & 1.5 & 18.69 & 262 \\
$\leq 28000$ & 20.2 & 28.4 & 8.6 & 20.29 & 527 \\
$29000-70000$ & 3.5 & 7.6 & 3.4 & 21.62 & 133 \\
$>70000$ & & & & \\
\hline \multicolumn{5}{c}{$\chi^{2}=48.45^{* *}$} \\
\hline Family size (member) & 13.6 & 18.4 & 7.3 & 20.73 & 362 \\
$\leq 4$ & 12.9 & 16.1 & 3.7 & 19.80 & 301 \\
5 & 12.1 & 13.4 & 2.5 & 19.31 & 259 \\
Above 5 & & & &
\end{tabular}




\begin{tabular}{|c|c|c|c|c|c|}
\hline \multirow{2}{*}{$\begin{array}{c}\text { Background } \\
\text { characteristics }\end{array}$} & \multicolumn{3}{|c|}{ BMI $\left(\mathrm{kg} / \mathrm{m}^{2}\right)$} & \multirow{2}{*}{$\begin{array}{c}\text { Mean } \\
\text { BMI } \\
\left(\mathrm{kg} / \mathrm{m}^{2}\right)\end{array}$} & \multirow{2}{*}{$\begin{array}{l}\text { No. of } \\
\text { respondents }\end{array}$} \\
\hline & $<18.5$ & 18.50 to 24.99 & $\geq 25.0$ & & \\
\hline \multicolumn{6}{|c|}{$\chi^{2}=15.18^{* *}$} \\
\hline \multicolumn{6}{|l|}{ Sibling size } \\
\hline 0 & 2.4 & 2.8 & 1.5 & 21.41 & 62 \\
\hline 1 & 14.1 & 21.1 & 7.0 & 20.58 & 390 \\
\hline 2 & 12.8 & 16.6 & 3.8 & 19.82 & 306 \\
\hline 3 and above & 9.3 & 7.4 & 1.1 & 18.60 & 164 \\
\hline \multicolumn{6}{|c|}{$\chi^{2}=27.97^{* *}$} \\
\hline \multicolumn{6}{|l|}{ Skipping \& cycling } \\
\hline No & 11.0 & 16.5 & 6.5 & 20.82 & 313 \\
\hline Yes & 27.7 & 31.5 & 6.9 & 19.62 & 609 \\
\hline \multicolumn{6}{|c|}{$\chi^{2}=16.51^{* *}$} \\
\hline \multicolumn{6}{|l|}{$\begin{array}{c}\text { Sporting activity per week } \\
\text { (hours) }\end{array}$} \\
\hline$\leq 3$ & 19.6 & 25.3 & 6.8 & 20.08 & 477 \\
\hline 4 to 6 & 6.3 & 9.4 & 3.6 & 20.73 & 178 \\
\hline Above 6 & 12.7 & 13.2 & 3.0 & 19.47 & 267 \\
\hline \multicolumn{6}{|c|}{$\chi^{2}=9.59^{*}$} \\
\hline \multicolumn{6}{|l|}{ Sleeping per day (hours) } \\
\hline$\leq 6$ & 10.0 & 8.8 & 3.4 & 19.83 & 204 \\
\hline 7 to 8 & 18.5 & 26.7 & 4.8 & 19.90 & 461 \\
\hline Above 8 & 10.1 & 12.5 & 5.3 & 20.49 & 257 \\
\hline \multicolumn{6}{|c|}{$\chi^{2}=20.87^{* *}$} \\
\hline
\end{tabular}

Table 2 continued

\begin{tabular}{cccccc}
$\begin{array}{c}\text { Food intake } \\
\text { Low }\end{array}$ & 0.5 & 0.5 & 0.5 & 17.23 & 15 \\
Normal & 32.0 & 30.7 & 4.9 & 19.13 & 623 \\
Rich & 6.1 & 16.7 & 8.0 & 22.09 & 284 \\
\hline \multicolumn{5}{c}{$\chi^{2}=98.45^{* *}$} \\
\hline Total & $\mathbf{3 8 . 6}$ & $\mathbf{4 7 . 9}$ & $\mathbf{1 3 . 5}$ & $\mathbf{n = 9 2 2}$ \\
& $\mathbf{( 3 5 6 )}$ & $\mathbf{( 4 4 2 )}$ & $\mathbf{( 1 2 4 )}$ & \\
\hline Overall & & $\mathbf{2 0 . 0 3}$ &
\end{tabular}

Note: Figures in parentheses indicate the number of respondents; **p<0.01, *p<0.05.

Results in the Table 2 show that the mean BMI is found to be quite low 
$\left(19.20 \mathrm{~kg} / \mathrm{m}^{2}\right)$ in the age group 9-11 years, which implies that the percentage of underweight is the highest in the early age group. The results show that there is significant difference between mean BMI among Muslim $\left(19.80 \mathrm{~kg} / \mathrm{m}^{2}\right)$ and nonMuslim $\left(20.88 \mathrm{~kg} / \mathrm{m}^{2}\right)$ girls because majority of the Muslim girls belong to both under and normal weight categories.

As expected, place of origin is significantly associated with girls nutritional status, which reveals that the percentage of underweight is considerably the highest (27.3\%) among the girls of rural origin followed by urban (8.4\%) and semi-urban (2.9\%) girls. Similar results have been observed in case of normal and overweight girls because majority of the respondents (69.8\%) place of origin was rural. The mean BMI is found lower among the girls who have rural origin $\left(19.77 \mathrm{~kg} / \mathrm{m}^{2}\right)$ compared to their semi-urban $\left(21.36 \mathrm{~kg} / \mathrm{m}^{2}\right)$ and urban $\left(20.32 \mathrm{~kg} / \mathrm{m}^{2}\right)$ counterparts. Like place of origin, current place of residence is also highly significantly associated with nutritional status of school girls. The findings illustrate that the percentage of underweight is the highest (26\%) in semi-urban girls while percentage of overweight is the highest (10\%) among those whose current place of residence is in urban areas. Thus, the differentials show that the mean BMI is found relatively high among the respondents living in the urban $\left(21.18 \mathrm{~kg} / \mathrm{m}^{2}\right)$ and low in semi-urban $\left(18.96 \mathrm{~kg} / \mathrm{m}^{2}\right)$ areas and the difference is $2.22 \mathrm{~kg} / \mathrm{m}^{2}$. Educational level has found associated with the nutritional status of the respondents. Findings in the Table 2 reflect that the percentage of normal weight is the highest (37.1\%) among those who read in class 6 to 8. Similar results are observed in case of under and over weights because most of the girls $(76.4 \%)$ currently reading between class 6 and class 8 . The highest mean 
BMI is computed as $20.28 \mathrm{~kg} / \mathrm{m}^{2}$ among the students of the aforesaid classes. The anthropometric measure like arm circumference is significantly associated with respondents' nutritional status. The mean BMI is extremely the highest $(25.68$ $\mathrm{kg} / \mathrm{m}^{2}$ ) among those whose arm circumference is above $15.5 \mathrm{~cm}$, consequently, the obesity is also found quite high in this stratum.

Like respondents education, fathers' education also has strong association with the respondents' nutritional status. The percentage of healthy girls is found to be the highest (37.1\%) whose fathers are highly educated. Similarly, the percentage of under and overweight girls are also relatively higher in the same category because majority of the respondents $(73.8 \%)$ belong to the families whose fathers educational level is above secondary. Table 2 shows that mean BMI are 18.26, 18.52 and $20.59 \mathrm{~kg} / \mathrm{m}^{2}$ among the girls whose fathers' education levels are below secondary, secondary and above secondary respectively. Mothers' education enhances child health through better knowledge, greater access to new information, and more efficient allocation of resources as well as through increasing the family income via maternal participation in economic activities [13]. In this research work, mothers' education is also found highly associated with the nutritional status of the girls. The findings reflect that the mean BMI of the girls is found the highest $\left(20.63 \mathrm{~kg} / \mathrm{m}^{2}\right)$ whose mothers education level is above secondary. The corresponding mean BMI is found the lowest (18.51 $\mathrm{kg} / \mathrm{m}^{2}$ ) whose mothers education level is below secondary.

Fathers' occupation has an important significant effect on girl's nutritional status. The mean BMI of the respondents is found the highest $\left(20.55 \mathrm{~kg} / \mathrm{m}^{2}\right)$ whose fathers 
are service holder. The percentage of overweight is also the highest (7\%) among the girls of the same group. Like fathers occupation, the mean BMI is relatively high $\left(20.49 \mathrm{~kg} / \mathrm{m}^{2}\right)$ among those whose mothers do job than those whose mothers are housewives $\left(19.91 \mathrm{~kg} / \mathrm{m}^{2}\right)$ because majority of the respondents whose mothers are housewives belong to under and normal weight categories. Previous studies showed that socio-economic status is positively associated with better nutritional status $[12,14]$. In this study, the similar results are also found regarding socioeconomic status and BMI of the school going girls. Findings from the Table 2 show that the mean BMI is found the lowest $\left(18.69 \mathrm{~kg} / \mathrm{m}^{2}\right)$ among respondents whose monthly family income is less than or equal to 28000 taka. The corresponding mean BMI is found the highest $\left(21.62 \mathrm{~kg} / \mathrm{m}^{2}\right)$ among the respondents whose monthly family income is above 70000 taka. The percentage of underweight, normal and overweight girls are found to be the highest $(20.2 \%, 28.4 \%$ and $8.6 \%$ respectively) whose monthly family income is $29000-70000$ taka because most of the respondents (57.2\%) belong to this stratum.

Family size has a significant effect on girl's nutritional status. The mean BMI is the highest $\left(20.73 \mathrm{~kg} / \mathrm{m}^{2}\right)$ among the respondents whose family members are less than or equal to four, which indicates that small family size is negatively associated with nutritional status of the girls. Like family size, sibling size is also an important factor of respondents' nutritional status. In a recent study carried out among Polish girls, greater height and BMI are found for children with sibling size 1-2 than 3 or more [15]. In this study, the mean BMI is found the highest $\left(21.41 \mathrm{~kg} / \mathrm{m}^{2}\right)$ among those who have no sibling. The results from the Table 2 show that the prevalence of 
healthy weighted girls is the highest $(31.5 \%)$ who have skipping and cycling habit. Duration of sporting activities is also associated with respondents' nutritional status. Mean BMI is the highest $\left(20.73 \mathrm{~kg} / \mathrm{m}^{2}\right)$ who have sporting habit 4 to 6 hours per week. Based on the results of the skipping \& cycling and also the duration of sporting activities, it can be concluded that regular physical exercise is an urgent need for better nutritional status of the girls.

The variable duration of sleeping is highly significantly associated with respondents' nutritional status. Result from the Table 2 shows that the percentage of overweight among the respondents is the highest $(5.3 \%)$ who sleep above 8 hours per day and their mean BMI is found high $\left(20.49 \mathrm{~kg} / \mathrm{m}^{2}\right)$ in this stratum. Food intake plays a significant role in the variation of nutritional status [16]. The percentage of underweight is the highest (32\%) among the girls who intake normal food because majority of the respondents $(67.6 \%)$ belong to low and normal intake groups. Mean BMI is the highest among the respondents who intake rich food $\left(22.09 \mathrm{~kg} / \mathrm{m}^{2}\right)$ followed by normal $\left(19.13 \mathrm{~kg} / \mathrm{m}^{2}\right)$ and low $\left(17.23 \mathrm{~kg} / \mathrm{m}^{2}\right)$ food. Thus, excessive intake of rich food should be avoided to reduce the obesity among school going girls.

Findings from the Table 2 along with discussions reveal that most of the selected background characteristics are found significantly associated with nutritional status of the school girls in Chittagong metropolitan area. The significant factors associated with respondents' nutritional status are religion, place of origin, current place of residence, respondents' education, arm circumference, fathers and mothers education and occupation, family income, family size, sibling size, skipping and 
54 Md Abdul Karim and Jesmin Akter

cycling, duration of sporting activity, sleeping and food intake.

In addition to study the association between nutritional status and associated factors, it is important to study further the interrelationship and causal relationship between BMI and other quantitative variables independently. To assess the amount of variation of BMI due to the unit change of explanatory variables, the analysis of regression is immensely important. Therefore, for better understanding and interpretations, the values of coefficient of correlation and regression are given in the Table 3.

Table 3. Results of interrelationship and causal relationship between BMI and some selected explanatory variables.

\begin{tabular}{|c|c|c|c|c|}
\hline \multirow[b]{2}{*}{ Variables } & \multicolumn{4}{|c|}{ BMI $\left(\mathrm{kg} / \mathrm{m}^{2}\right)$} \\
\hline & $\begin{array}{c}\text { Simple } \\
\text { correlation } \\
\text { Coefficient (r) }\end{array}$ & $\begin{array}{c}P- \\
\text { value }\end{array}$ & $\begin{array}{c}\text { Simple } \\
\text { regression } \\
\text { Coefficient }(b)\end{array}$ & $\begin{array}{c}\text { P- } \\
\text { value }\end{array}$ \\
\hline Respondents' current age (years) & 0.08 & .013 & 0.26 & .013 \\
\hline Respondents' education in single years & 0.06 & .075 & 0.19 & .075 \\
\hline Arm circumference $(\mathrm{cm})$ & 0.80 & .000 & 2.81 & .000 \\
\hline Family income (Tk.) & 0.21 & .000 & 0.023 & .000 \\
\hline Sporting activities (hours) & -0.10 & .004 & -0.12 & .004 \\
\hline Fathers education in single years & 0.21 & .000 & 0.21 & .000 \\
\hline Mothers education in single years & 0.23 & .000 & 0.22 & .000 \\
\hline Family size & -0.13 & .000 & -0.35 & .000 \\
\hline
\end{tabular}




\begin{tabular}{|l|c|c|c|c|}
\hline Sibling size & -0.18 & .000 & -0.72 & .000 \\
\hline Sleeping (hours) & 0.05 & .122 & 0.06 & .122 \\
\hline
\end{tabular}

Results in the Table 3 show that BMI is significantly positively correlated with respondents' current age (0.08), arm circumference (0.80), family income (0.21), fathers' education (0.21), mothers' education (0.23) and sleeping (0.05), and negatively correlated with duration of sporting activities $(-0.10)$, family size $(-0.13)$ and sibling size (-0.18). The regression coefficients indicate that with the increase of respondents' mother's education by one year, BMI is likely to be increased by $0.22 \mathrm{~kg} / \mathrm{m}^{2}$ and with the increase of sibling size by one member, BMI is likely to be decreased by $0.72 \mathrm{~kg} / \mathrm{m}^{2}$.

In addition to study the association of attributes and interrelationship, and also the causal relationship of BMI, it is very important to identify the prognostic factors and relative importance of all the variables simultaneously employing a multivariate analysis. In this kind of study, multiple regression analysis and discriminant analysis are difficult where the most of the dependent variables are categorical. Therefore, it is relatively better to employ multinomial logistic regression since the dependent variable (BMI) is tri-chotomous in nature. The logic behind to use multinomial logistic regression model is that this type of model can be used not only to identify the prognostic factors but also to predict the probability of success. In addition, this technique can appropriately handle the situations in which the dependent variable is qualitative or measured in nominal or ordinal scales as a function of dependent variable, both qualitative and quantitative. Moreover, it does not require distributional assumptions concerning explanatory variables. 
56 Md Abdul Karim and Jesmin Akter

Before employing multinomial logistic regression, multicollinearity test among the explanatory variables considered in the model were carried out using variance inflation factor (VIF) and constructing correlation matrix because in presence of multicoliniearity the estimates could be biased. The VIF for explanatory variables $X_{j}$ are:

$$
V I F_{j}=\frac{1}{\left(1-R_{j}^{2}\right)} ; \quad \text { for } \mathrm{j}=1,2, \ldots \ldots \ldots, \mathrm{k}
$$

Where, $\mathrm{k}$ is the number of predictor variables and $R_{j}{ }^{2}$ is the square of the multiple correlation coefficient of the $j^{t} \quad$ variable with the remaining k-1 variables. On the basis of the values of collinearity statistic and correlation matrix, the variables fathers' and mothers' education are found highly inter-correlated. Therefore, the explanatory variable mother's education has been dropped out from the multinomial logistic regression analysis.

In the multinomial logit model, we assume that the log-odds of each response follow a linear model:

$$
h_{i j}=\log \frac{p_{i j}}{p_{i j}}=\alpha_{j}+x_{i} \beta_{j}
$$

Where, $\alpha_{j}$ is a constant and $\beta_{j}$ is a vector of regression coefficients, for $\mathrm{j}=1,2, . ., \mathrm{J}-1$.

$\mathrm{X}$ is a data matrix.

This model is analogous to logistic regression model, except that the probability distribution of the response is multinomial instead of binomial and we have J-1 equations instead of one. The J-1 multinomial logit equations contrast each of 
categories $1,2, \ldots, \mathrm{J}-1$ with category $\mathrm{J}$, whereas, the single logistic regression equation is a contrast between success and failures. If $\mathrm{J}=2$, the multinomial logit model reduces to the usual logistic regression model. Nonetheless, we need only J-1 equations to describe a variable with $\mathrm{J}$ response categories and that it really makes no difference which category we pick as the reference cell, because we can always convert from one formulation to another.

After testing the multicollinearity, the multinomial regression model was fitted accordingly and the results are given in the Table 4. In this study, the effect of predictor variables on nutritional status of the school girls is indicated by the odds ratio of each category relative to reference category.

Table 4. Multinomial logistic regression estimates for the simultaneous effect of background characteristics in the model of nutritional status among school girls in Chittagong metropolitan area.

\begin{tabular}{|c|c|c|c|c|c|c|}
\hline \multirow[b]{2}{*}{$\begin{array}{l}\text { Background } \\
\text { characteristics }\end{array}$} & \multicolumn{3}{|c|}{ BMI (18.50 to 24.99$)$} & \multicolumn{3}{|c|}{ BMI $(\geq 25.0)$} \\
\hline & Coefficient & $\begin{array}{l}\text { Wald, } \\
\text { Chi- } \\
\text { square }\end{array}$ & $\begin{array}{l}\text { Odds } \\
\text { ratio }\end{array}$ & Coefficient & $\begin{array}{l}\text { Wald, } \\
\text { Chi- } \\
\text { square }\end{array}$ & $\begin{array}{l}\text { Odds } \\
\text { ratio }\end{array}$ \\
\hline Intercept & $4.54^{* *}$ & 15.19 & & $4.48 * *$ & 9.75 & \\
\hline Religion & \multicolumn{6}{|c|}{0.101} \\
\hline Muslim & $-0.47^{*}$ & 3.99 & 0.63 & -0.62 & 2.79 & 0.54 \\
\hline Others (RC) & - & - & - & - & - & - \\
\hline Place of origin & \multicolumn{6}{|c|}{0.236} \\
\hline Rural & 0.08 & 0.12 & 1.08 & -0.49 & 1.74 & 0.61 \\
\hline Semi-urban & -0.34 & 0.86 & 0.72 & -0.28 & 0.25 & 0.76 \\
\hline Urban(RC) & - & - & - & - & - & - \\
\hline
\end{tabular}


Md Abdul Karim and Jesmin Akter

\begin{tabular}{|c|c|c|c|c|c|c|}
\hline \multirow[b]{2}{*}{$\begin{array}{l}\text { Background } \\
\text { characteristics }\end{array}$} & \multicolumn{3}{|c|}{ BMI (18.50 to 24.99) } & \multicolumn{3}{|c|}{ BMI $(\geq 25.0)$} \\
\hline & Coefficient & $\begin{array}{c}\text { Wald, } \\
\text { Chi- } \\
\text { square }\end{array}$ & $\begin{array}{l}\text { Odds } \\
\text { ratio }\end{array}$ & Coefficient & $\begin{array}{c}\text { Wald, } \\
\text { Chi- } \\
\text { square }\end{array}$ & $\begin{array}{l}\text { Odds } \\
\text { ratio }\end{array}$ \\
\hline $\begin{array}{l}\text { Current place of } \\
\text { residence }\end{array}$ & \multicolumn{6}{|c|}{0.003} \\
\hline Semi-urban & $-0.58^{* *}$ & 8.25 & 0.56 & $-1.03^{* *}$ & 8.60 & 0.36 \\
\hline Urban (RC) & - & - & - & - & - & - \\
\hline $\begin{array}{l}\text { Respondents' education } \\
\text { (class) }\end{array}$ & \multicolumn{6}{|c|}{0.168} \\
\hline 5 & 0.03 & 0.01 & 1.03 & -0.34 & 0.19 & 0.71 \\
\hline 6 to 8 & 0.43 & 3.18 & 1.53 & 0.73 & 2.31 & 2.06 \\
\hline 9 to $10(\mathrm{RC})$ & - & - & - & - & - & - \\
\hline Arm Circumference(cm) & \multicolumn{6}{|c|}{0.000} \\
\hline$\leq 13.9$ & $-5.04^{* *}$ & 23.66 & 0.01 & $-9.02^{* *}$ & 50.96 & 0.000 \\
\hline $14.0-15.5$ & $-2.96^{* *}$ & 8.30 & 0.05 & $-5.68^{* *}$ & 29.62 & 0.003 \\
\hline Above 15.5 (RC) & - & - & - & - & - & - \\
\hline Father's education & \multicolumn{6}{|c|}{0.219} \\
\hline Below secondary & -0.57 & 2.34 & 0.57 & 0.16 & 0.04 & 1.17 \\
\hline Secondary & -0.23 & 0.74 & 0.80 & -0.94 & 2.09 & 0.39 \\
\hline Above secondary(RC) & - & - & - & - & - & - \\
\hline
\end{tabular}

Table 4 continued

\begin{tabular}{lcccccc}
\hline Father's occupation & \multicolumn{7}{c}{$\mathbf{0 . 1 2 3}$} \\
\hline Business & -0.01 & 0.01 & 0.98 & $1.27^{*}$ & 5.04 & 3.54 \\
Service & -0.13 & 0.26 & 0.87 & 0.90 & 2.40 & 2.45 \\
Others (RC) & - & - & - & - & - & - \\
\hline Mother's occupation & \multicolumn{7}{c}{$\mathbf{0 . 0 4 8}$} \\
\hline House wife & $-0.56^{*}$ & 5.77 & 0.57 & -0.36 & 0.89 & 0.70 \\
Service (RC) & - & & - & - & - & - \\
\hline Monthly family & & & $\mathbf{0 . 6 2 2}$ & & \\
income(Tk.) & & & & & & \\
\hline$\leq 28000$ & 0.29 & 0.63 & 1.34 & -0.40 & 0.37 & 0.67 \\
$29000-70000$ & 0.28 & 0.93 & 1.32 & 0.22 & 0.27 & 1.24 \\
$>70000(\mathrm{RC})$ & - & - & - & - & - & -
\end{tabular}




\begin{tabular}{|c|c|c|c|c|c|c|}
\hline \multirow[b]{2}{*}{$\begin{array}{c}\text { Background } \\
\text { characteristics }\end{array}$} & \multicolumn{3}{|c|}{ BMI (18.50 to 24.99) } & \multicolumn{3}{|c|}{ BMI $(\geq 25.0)$} \\
\hline & Coefficient & $\begin{array}{c}\text { Wald, } \\
\text { Chi- } \\
\text { square }\end{array}$ & $\begin{array}{l}\text { Odds } \\
\text { ratio }\end{array}$ & Coefficient & $\begin{array}{c}\text { Wald, } \\
\text { Chi- } \\
\text { square }\end{array}$ & $\begin{array}{l}\text { Odds } \\
\text { ratio }\end{array}$ \\
\hline Family size(members) & \multicolumn{6}{|c|}{0.262} \\
\hline$\leq 4$ & -0.30 & 0.87 & 0.74 & 0.37 & 0.47 & 1.44 \\
\hline 5 & -0.18 & 0.34 & 0.84 & -0.39 & 0.52 & 0.68 \\
\hline Above 5 (RC) & - & - & - & - & - & - \\
\hline Sibling size & \multicolumn{6}{|c|}{0.350} \\
\hline 0 & 0.30 & 0.40 & 1.35 & 1.00 & 1.42 & 2.72 \\
\hline 1 & 0.64 & 2.95 & 1.89 & 0.61 & 0.78 & 1.85 \\
\hline 2 & 0.49 & 2.06 & 1.63 & 0.98 & 2.11 & 2.65 \\
\hline 3 and above (RC) & - & - & - & - & - & - \\
\hline Skipping \& cycling & \multicolumn{6}{|c|}{0.292} \\
\hline No & 0.06 & 0.09 & 1.06 & 0.46 & 2.23 & 1.59 \\
\hline Yes $(\mathrm{RC})$ & - & - & - & - & - & - \\
\hline $\begin{array}{l}\text { Sporting activities per } \\
\text { week (hours) }\end{array}$ & \multicolumn{6}{|c|}{0.594} \\
\hline$\leq 3$ & 0.20 & 1.05 & 1.23 & 0.10 & 0.07 & 1.10 \\
\hline 4 to 6 & 0.21 & 0.64 & 1.23 & 0.51 & 1.41 & 1.66 \\
\hline Above $6(\mathrm{RC})$ & - & - & - & - & - & - \\
\hline
\end{tabular}

Table 4 continued

\begin{tabular}{|c|c|c|c|c|c|c|}
\hline Sleeping per day (hours) & \multicolumn{6}{|c|}{0.001} \\
\hline$\leq 6$ & $-0.56^{*}$ & 4.84 & 0.57 & -0.52 & 1.74 & 0.59 \\
\hline 7 to 8 & 0.10 & 0.22 & 1.11 & $-0.76^{*}$ & 4.59 & 0.47 \\
\hline Above 8 (RC) & - & - & - & - & - & - \\
\hline Food intake & \multicolumn{6}{|c|}{0.033} \\
\hline Low \& normal & $-0.53^{*}$ & 5.91 & 0.59 & $-0.69^{*}$ & 4.22 & 0.50 \\
\hline Rich (RC) & - & - & - & - & - & - \\
\hline \multicolumn{7}{|l|}{$\begin{array}{l}\text { Model fitting } \\
\text { information }\end{array}$} \\
\hline -2log likelihood & \multicolumn{6}{|c|}{1237.00} \\
\hline Chi-square & \multicolumn{6}{|c|}{570.13} \\
\hline p-value & \multicolumn{6}{|c|}{0.000} \\
\hline
\end{tabular}


60 Md Abdul Karim and Jesmin Akter

Note: $(R C)$ indicates reference category; Reference category of dependent variable is underweight of school girls;** $<<0.01, * p<0.05, n=922$.

Results in the Table 4 at a glance indicate that place of residence, arm circumference, mothers' occupation, duration of sleeping and food intake of the respondents are found significant predictors of BMI while religion is found significant only in bivariate analysis. The findings show that girls residing in semi-urban area have $44 \%$ lower probability of becoming nourished and 64\% lower probability of becoming overweight compared to their urban counterparts. Surprisingly, the respondents' whose arm circumference is $\leq 13.9$ and $14.0-15.5 \mathrm{~cm}$ have $99 \%$ and $95 \%$ lower probability of becoming nourished compared to those whose arm circumference is above $15.5 \mathrm{~cm}$. Moreover, the respondents' whose arm circumference is in the group 14.0-15.5 cm have 0.003 times lower probability of becoming overweight compared to respondents' whose arm circumference is above $15.5 \mathrm{~cm}$.

Occupational status of the mothers of the respondents state that the girls whose mothers are housewives have $43 \%$ lower probability of becoming nourished and $30 \%$ lower probability $(\operatorname{Exp}(\beta)=0.57 ; 0.70)$ of becoming overweight compared to those whose mothers do job. Results in the Table 4 also show that sleeping habit plays an important role on the nutritional status of the school girls. The odds ratio show that the probability of being nourished was $43 \%$ lower among the respondents who have sleeping habit $\leq 6$ compared to those who have sleeping habit above 8 hours per day. Similarly, the corresponding probability of being overweight were $41 \%$ and $53 \%$ lower compared to the respondents who have sleeping habit above 8 hours per day. In the context of food habit, it was observed 
that among the respondents who intake low and normal foods have $41 \%$ lower probability of becoming nourished and 50\% lower probability of becoming overweight compared to those who intake rich food, which indicates that rich food is a predominant factor responsible for obesity among female teenagers. Based on the test statistic and corresponding p-value (0.000), it can be concluded that the overall multinomial logistic regression model of the study is found highly significant.

\section{Conclusions and Policy Implications}

The purpose of this research study is to investigate the determinants of nutritional status among school girls in Chittagong metropolitan area. The findings show that still more than half $(52.1 \%)$ of the school girls are found malnourished. Since education is one of the prime determinants of nutritional status, therefore, students need proper education about the nutritional contents of food, particularly about fat and junk food in order to make appropriate food choices. The healthy girls are found the highest in the age group 12-13 years. Nevertheless, the percentage of underweight and overweight are also found relatively higher in the same group. The reason behind this they have the tendency for taking health-care independently. Religion differentials of BMI show that there is significant difference in mean BMI among Muslim and non-Muslim girls. In Bangladesh, the vast majority Muslim girls have religious taboos, conservative and posses a story influence on dietary habits. Current place of residence have wide variations in the contexts of BMI, probably because of the residential disparity among the respondents in respect to socio-economic condition as well as levels of fathers and mothers education. The original disparity of nutritional status among 
school girls have observed in this study due to social discrimination, cultural differences and inequality of mental development process. The higher percentage of overweight among urban girls is undoubtedly a great concern, which indicates that a higher percentage of respondents in urban areas lead luxurious life and that is why they are reluctant to do any type of physical work. Conversely, the girls residing in semiurban areas do struggle to lead normal life; they still do not get adequate nutritious food. An educated father normally aware of food value and that is why their daughters take nutritious food. Girls belong to such types of socially advanced families do not get enough time to do physical exercise because they are usually engaged with different types of electronic devices and social media for their amusements. In addition, there is no open place for doing physical work in urban settings, which might be an important cause of overweight. The findings also reflect that girls of higher educated mothers are more likely to obese than those whose education levels are lower. The reason is that a more educated mother has freedom to earn and to make decision on household purchase including foods. Thus, in the urban contexts, maternal education may be considered as a good proxy for the standard of living. Moreover, fathers' occupation is also the most influencing factor for girls' BMI.

The percentage of overweight respondents are found higher in higher socio-economic stratum because they lead a luxurious life and specially depend on excessive use of cars and other fuel based vehicles, watching TV programs, the availability of fast foods and less spending time for walking and physical activities. Girls are found underweight in lower socio-economic status as they do not get adequate privilege to lead their life. The highest BMI are found among those whose family members are 
up to four. Respondents of this ideal category have access to adequate food supplies, use of health service, availability of improved water resources and sanitation facilities, which are important determinants of nutritional status. Sibling size has found significant effect on nutritional status. Girls who have fewer siblings are found overweight due to more food intake and medical care, and make better choices among abundance of foods. Respondents who have habit of sporting activities are observed less overweight than the respondents who have no sporting activities because the less one moves around the fewer calories one burns. The percentage of overweight respondents is observed to be higher in the group who intake rich food because the availability of fast and fatty foods and less spending time for walking and physical activities.

Although the media has highlighted the importance of low fat and low cholesterol foods in one's diet, unexpectedly, it shows that family members and their children's are still consuming harmful fast food, junk food and preserved food. To overcome the problem of teenage girls' obesity, girls need to balance the calories they usually consume from foods and beverages and should change their dietary habits.

Based on the findings of this research work, it can be suggested that fruitful policies should be adopted by the concerned authorities to ensure better nutritional status among the school girls for the reduction of infant, child, maternal mortality and morbidity in future. Therefore, the following specific recommendations may be suggested, which could help the population scientists, demographers, policy makers and NGO workers to implement appropriate programs for improving nutritional status of the girls in Bangladesh:

i) Girls in urban areas are more vulnerable to be overweight. Thus, necessary 
64 Md Abdul Karim and Jesmin Akter

steps along with counseling should be taken among the girls to increase awareness about bad effects of junk food and less physical work. Electronics and print media can play a vital role in this context;

ii) Each and every school must be established a health care center and should measure each student's BMI at a regular time interval and provide the results to the students and also their families;

iii) Teachers might engage students in whole-class discussions, debates and presentations about bad consequences of obesity;

iv) Since girls residing in semi-urban area is belong to underweight stratum, therefore, it may be necessary to create greater access to health services and awareness about the importance of health services and nutrition education and micronutrient supplements;

v) Appropriate measures should be taken by the concerned authorities to support the poor and to bring rapid economic growth at the national economic level along with attaining good health, fertility and national productivity;

vi) Parents must play a key role by providing balance foods in home and encouraging physical activities to their daughters;

vii) Awareness should be created among the girls about bad effects of insufficient and as well as over sleeping habit;

viii) School authorities should expand opportunities for all students to engage at least 30 minutes of moderate to vigorous physical activity regularly and

ix) Finally, close relationship between the government and concerned authorities regarding the activities about the health condition of school 
going girls' could be the best alternative for improving the nutritional status of the school girls.

Proper implementation of the aforesaid recommendations by the concerned authorities could be helpful to reduce at a greater extent the percentage of underweight and overweight, which ultimately likely to be ensured the balanced nutritional status of school girls in Bangladesh. Finally, based on the findings of this research work it can be concluded that balanced and well nutritional status of school girls is a precondition for better and safe life, good reproductive health, healthy mother along with their healthy offspring as well as for the healthy nation because today's girls will be the tomorrow's mothers.

\section{References}

[1] A. Keys, J. Brozek, A. Henschel, O. Michelsen, H. L. Taylor, E. Simonson and S. M. Wells : "The Biology of Human Starvation, Volumes 1 and 2", Univ. Minnesota Press, Minneapolis, 1950.

[2] R. Schofield : The Journal of Interdisciplinary History, 1983, 14(2), 265.

[3] J. Komlos : Social Science History, 1990, 14(1), 69.

[4] S. Sidhu and M. Kaushal : Indian Journal of Physical Anthropology and Human Genetics, 2005, 24, 87.

[5] J. Bryce, D. Coitinho, I. Darnton-Hill, D. Pelletier and P. Pinstrup-Andersen : The Lancet, 2008, 371(9611), 510. 
[6] A. S. G. Faruque, A. M. S. Ahmed, T. Ahmed, M. M. Islam, M. I. Hossain, S. K. Roy, N. Alam, I. Kabir and D. A. Sack : Journal of Health, Population and Nutrition, 2008, 26(3), 325.

[7] T. Lobstein, L. Baur and R. Uauy : Obesity Reviews, 2004, 5, 4.

[8] K. Krasovec and M. A. Anderson : "Maternal Nutrition and Pregnancy Outcomes : Anthropometric Assessment", Pan American Health Organization, 1991.

[9] J. Bongaarts : Studies in Family Planning, 1980, 11(12), 401.

[10] B. L. Pierce, T. Kalra, M. Argos, F. Parvez, Y. Chen, T. Islam and P. J. Rathouz : International Journal of Epidemiology, 2009, 39(4), 1037.

[11] S. Shafique, N. Akhter, G. Stallkamp, S. de Pee, D. Panagides and M. W. Bloem : International Journal of Epidemiology, 2007, 36(2), 449.

[12] M. M. Khan and A. Krämer : Singapore Medical Journal, 2009, 50(8), 804.

[13] B. A. Levandowski, P. Sharma, S. D. Lane, N. Webster, A. M. Nestor, D. A. Cibula and S. Huntington : Health Promotion Practice, 2006, 7(1), 95.

[14] S. M. Kamal and M. A. Islam : Malaysian Journal of Nutrition, 2010, 16(3), 349.

[15] E. Suliga : Annals of Human Biology, 2009, 36(2), 199.

[16] D. M. Matheson, J. Varady, A. Varady and J. D. Killen : The American Journal of Clinical Nutrition, 2002, 76(1), 210.

Manuscript received on 15 July, 2019, Revised manuscript received on 02 October, 2019 and accepted on 29 December, 2019

The Chittagong Univ. J. Sc. Vol. 41(1), 2019 